\title{
Performance and environmental accounting of nutrient cycling models to estimate nitrogen emissions in agriculture and their sensitivity in life cycle assessment
}

\author{
Edilene Pereira Andrade ${ }^{1,2}{ }^{10} \cdot$ August Bonmati $^{1} \cdot$ Laureano Jimenez Esteller $^{2} \cdot$ Erica Montemayor $^{1,3}$. \\ Assumpcio Anton Vallejo ${ }^{1}$
}

Received: 22 September 2020 / Accepted: 4 January 2021 /Published online: 4 February 2021

(c) The Author(s) 2021

\begin{abstract}
Purpose Several models are available in the literature to estimate agricultural emissions. From life cycle assessment (LCA) perspective, there is no standardized procedure for estimating emissions of nitrogen or other nutrients. This article aims to compare four agricultural models (PEF, SALCA, Daisy and Animo) with different complexity levels and test their suitability and sensitivity in LCA.

Methods Required input data, obtained outputs, and main characteristics of the models are presented. Then, the performance of the models was evaluated according to their potential feasibility to be used in estimating nitrogen emissions in LCA using an adapted version of the criteria proposed by the United Nations Framework Convention on Climate Change (UNFCCC), and other relevant studies, to judge their suitability in LCA. Finally, nitrogen emissions from a case study of irrigated maize in Spain were estimated using the selected models and were tested in a full LCA to characterize the impacts.

Results and discussion According to the set of criteria, the models scored, from best to worst: Daisy (77\%), SALCA (74\%), Animo (72\%) and PEF (70\%), being Daisy the most suitable model to LCA framework. Regarding the case study, the estimated emissions agreed to literature data for the irrigated corn crop in Spain and the Mediterranean, except $\mathrm{N}_{2} \mathrm{O}$ emissions. The impact characterization showed differences of up to $56 \%$ for the most relevant impact categories when considering nitrogen emissions. Additionally, an overview of the models used to estimate nitrogen emissions in LCA studies showed that many models have been used, but not always in a suitable or justified manner.

Conclusions Although mechanistic models are more laborious, mainly due to the amount of input data required, this study shows that Daisy could be a suitable model to estimate emissions when fertilizer application is relevant for the environmental study. In addition, and due to LCA urgently needing a solid methodology to estimate nitrogen emissions, mechanistic models such as Daisy could be used to estimate default values for different archetype scenarios.
\end{abstract}

Keywords IPCC TIERs $\cdot$ UNFCCC $\cdot$ Nitrate leaching $\cdot$ Ammonia volatilization $\cdot$ Nitrous oxide $\cdot$ PEF $\cdot$ Daisy $\cdot$ Animo $\cdot$ SALCA IPCC TIERs

\section{Introduction}

Communicated by Greg Thoma

Edilene Pereira Andrade

edilene.pereira@irta.cat

1 Institute of Agrifood Research and Technology. Torre Marimon, 08140 Caldes de Montbui, Barcelona, Spain

2 Departament D'Enginyeria Química, Universitat Rovira I Virgili, Av. Països Catalans, 26, 43007 Tarragona, Spain

3 Department of Civil and Environmental Engineering, Universitat Politécnica de Catalunya (UPC), Carrer de Jordi Girona, 1-3, 08034 Barcelona, Spain
Appropriate resource management in agricultural systems is the responsibility and a challenge of the agronomic sector and environmental policies, especially to match growing demand and crop production (Wuepper et al. 2020). The objective of agricultural production is to provide safe and good quality food in such a way to minimize adverse impacts on the environment. To sustain food production, around $75 \%$ of the reactive nitrogen added to agroecosystems is created by human activities, and the excess of nutrients is a severe problem and threatens the environmental 
balance (Rockström et al. 2009). In particular, nitrogen (N) emissions to air, soil and water may have several adverse effects. For instance, climate change is affected by nitrous oxide $\left(\mathrm{N}_{2} \mathrm{O}\right)$ emissions, and nitrogen oxides $\left(\mathrm{NO}_{\mathrm{x}}\right)$ form acid when interacting with water, oxygen and other chemicals, contributing to acidification (Frischknecht and Jolliet 2016). In the same way, marine eutrophication is the consequence of nitrate $\left(\mathrm{NO}_{3}^{-}\right.$) emission exposure to aquatic systems (Wolf 2010) and pollution of groundwater due to $\mathrm{NO}_{3}^{-}$leaching may cause a decrease in freshwater resource quality and hence affect human health (Ward et al. 2018).

For assessing impacts from agriculture, the life cycle assessment (LCA) is a broadly accepted and used methodology (Notarnicola et al. 2017; Nitschelm et al. 2018). Agricultural systems LCA can use LCA to calculate the environmental costs on goods and services by quantifying all emissions and resource consumption. However, to use LCA, there is a need to estimate the sources of nutrients (e.g. nitrogen, phosphorus) responsible for the most significant impacts on the environment (Groenendijk et al. 2005).

According to input data needs and the degree of complexity, the IPCC (2006) classifies in three different tiers, the methodological approaches for estimating nutrient emissions. Models that are considered Tier 1 use the default emission factors (EF) provided, for instance, by IPCC. Tier 2 models are very similar to Tier 1, but EFs and other parameters applied are country-specific. Tier 3 models are the most detailed; therefore, it can estimate the emissions with greater certainty than Tiers 1 and 2 .

While there is no standardized methodology or models to estimate nutrient emissions in LCA, many methodologies have been used. Brentrup et al. (2000) proposed Tier 1 and Tier 2 models to estimate the most important nitrogen emissions $\left(\mathrm{NH}_{3}, \mathrm{~N}_{2} \mathrm{O}, \mathrm{NO}_{3}^{-}\right)$related to agricultural production in LCA. Tier 2 models, for instance, SALCA (Nemecek et al. 2016) and AGRYBALYSE (Koch and Salou 2015), and Tier 3 models, such as DAYCENT in Kim and Dale (2005), DNDC in Goglio et al. (2014) and STICS in Plaza-Bonilla et al. (2018), have also been used to estimate nitrogen emissions in LCA.

The guideline "Nutrient flows and associated environmental impacts in livestock supply chains" (FAO 2018) provides recommendations for building inventories in life cycle assessment (LCA) regarding the level of specificity of the study. Tier 1 is recommended for a screening analysis that allows the practitioner to overview the hotspots in the studied system. Tier 2 is recommended for supply chain and regional assessments, and Tier 3 should be applied to the product system. However, since those are recommendations, LCA practitioners are not forced to choose one model or other, but, for example, as Perrin et al. (2014) claimed, models used to estimate emissions can sometimes be used in inappropriate domains they were created.
In this sense, two Tier 3 dynamic models Animo and Daisy, the Tier 2 LCA emission method SALCA (Nemecek et al. 2015), and the Product Environmental Footprint (PEF) (EC-PEFCR 2018) were applied to estimate nitrogen emissions from agriculture in LCA. The two dynamic Tier 3 models, Animo (Rijtema and Kroes 1991) and Daisy (Hansen 2000), have been used to estimate the nitrogen emissions to soil, air and water under the scope of the European Union's Horizon 2020 Project Nutri2Cycle (Grant agreement No 773682, https://www.nutri2cycle.eu/). The different models (for terminology consistency, all approaches will be referred to as models) are compared and discussed, considering their requirements and main characteristics. The specific aims of this study can be divided into the following:

1. Provide an overview of the selected models to understand their main characteristics and application in agricultural systems;

2. Compare PEF, SALCA, Daisy and Animo under the adapted criteria from the United Nations Framework Convention on Climate Change (UNFCCC) and other relevant studies to judge their suitability in LCA framework;

3. Perform a quantitative comparison using an irrigated maize production case study in Spain. Additionally, impacts were characterized considering the different emissions estimated;

4. Discuss how nitrogen emissions have been estimated in LCA agricultural studies found in literature and suggest how nutrient emission models should be used in LCA.

\section{Methods}

The assessment of the different emission accounting models included several steps:

1. Contextual background of the models (Sect. 2.1);

2. Introduction to the $\mathrm{N}$ cycle and its consideration and adaptation in the models (Sect. 2.2);

3. Description of criteria and subcriteria for the models' evaluation (Sect. 2.3);

4. Description of the case study performed (Sect. 2.4).

\subsection{Contextual background of the models}

In this section, an overview of the models is provided, also their application in agricultural systems.

The European Commission's and the Joint Research Center (JRC) developed the PEF model. The Swiss Confederation center for agricultural research (Agroscope) developed and recommended methods that established SALCA. The Agrohydrology group at the University of 
Copenhagen developed the mechanistic simulation model of agricultural field model, Daisy, and Wageningen University and Research is the institution behind Animo model.

Regarding spatial scale, Daisy and Animo present the most detailed scale, site-specific nutrient emissions. SALCA appears to be the most limited in reproducing emission estimates, due to its focus on crops and farms in Europe or in temperate climate zone. PEF does not cover spatial scale.

SALCA, Daisy and Animo provide default crop parameters in the models' library. These default values are crucial for LCA practitioners who wish to use dynamic models to estimate emissions. Still, they do not have sufficiently detailed information to create a new crop dataset. The common crops simulated in all models are maize, potatoes, grassland and wheat.

One way to judge the accuracy and precision of a model is through validation of its parameters. Those parameters may come from field observations, model calibration, or user expertise (Hansen et al. 2012). Model calibration in Animo and Daisy can use yield. A simplified validation of the results can be made based on literature data from other studies, on similar conditions. PEF, SALCA, Daisy and Animo have already been calibrated and validated under different climatic types defined by Koppen-Geiger (Table 1).

PEF and SALCA are considered user-friendly models, due to its simplicity (PEF), adaptation to spreadsheets and use of parameters from literature (SALCA). Although Animo and Daisy cannot be considered as user-friendly models, due to the programming and the amount of input data required for the models, spreadsheet files or text editors are used to read their outputs.

All models provide a compiled bibliography (i.e. user guide, references, tutorial), which is especially helpful for non-experts or the beginners in the models. Moreover, Daisy offers strategies to deal with the lack of data, guiding users to minimize the effect of the assumptions on results and providing user support to help understand the model and the simulations performed. Strategies for unavailable data and user support for SALCA and, especially, for Animo would be useful for the practitioners.

Regarding the suitability of the models in LCA, SALCA and PEF were explicitly developed for LCA studies. Daisy and Animo are compatible with the LCA methodology since they provide the necessary emissions. Daisy was used to estimating emissions in LCA for garden waste management options (ten Hoeve et al. 2019), to quantify greenhouse gas emissions (Jensen et al. 2017), and estimate emissions in Danish cereal cropping systems (Kløverpris et al. 2016). SALCA, initially developed for Switzerland, has been extended to other countries with a temperate climate and has been used in several European projects that include LCA in its scope. PEF has already been used to assess the environmental performance of different agricultural products such as wines, pasta and dairy products. Animo has not yet been used in LCA.

Uncertainty and sensitivity analyses are fundamental in LCA studies because it can estimate emission ranges for results and can develop scenarios appropriately. SALCA is the only model that does not consider the sensitivity and uncertainty of their parameters. The uncertainty and sensitivity of IPCC emission factors are considered for PEF. The uncertainty in Daisy was evaluated for the input parameters, obtaining a range between 5 to $95 \%$ comparing the measured monthly soil water content and the estimates from the model (Salazar et al. 2013). Jabloun et al. (2016) analysed the sensitivity of the outputs showing that the weather conditions substantially influence the Daisy's outputs. Kroes and Roelsma (2007) evaluated the uncertainty related to the hydraulic parameters (measured and estimated) in Animo and concluded that there is a little influence ( $<3 \%$ changes) on nitrate leaching. Hendriks et al. (1999) focused on solute transport adaptations in Animo, where demonstrated high sensitivity to oxygen diffusion parameters and can influence nitrogen processes such as mineralization, nitrification and denitrification.
Table 1 Summary of reproducibility and climate validation under different conditions

\begin{tabular}{lllll}
\hline Climate & PEF & SALCA & Daisy & Animo \\
\hline Tropical/megathermal & $\mathrm{Y}^{*}$ & $\mathrm{~N}$ & $\mathrm{~N}$ & Pinto (2016) \\
Dry (desert and semiarid) & $\mathrm{Y}^{*}$ & $\mathrm{~N}$ & Manevski et al. (2016) & Farmaha (2014) \\
Temperate/mesothermal & $\mathrm{Y}^{*}$ & Nemecek & Mueller et al. (1997) & Rijtema and Kroes (1991) \\
& & $\begin{array}{l}\text { et al. } \\
(2006)\end{array}$ & & \\
Continental/microthermal & $\mathrm{Y}^{*}$ & $\mathrm{~N}$ & Pohanková et al. (2015) & Marinov et al. (2005) \\
Polar & $\mathrm{Y}^{*}$ & $\mathrm{~N}$ & $\mathrm{~N}$ & $\mathrm{~N}$ \\
Extreme weather conditions & $\mathrm{Y}^{*}$ & $\mathrm{~N}$ & $\mathrm{~N}$ & Hendriks and Akker (2017) \\
\hline
\end{tabular}

*The PEF was created to be used worldwide, and there is no restriction for application in different climate conditions 


\subsection{Introduction to the $\mathbf{N}$ cycle and its adaptation in the models}

In this section, the models' consideration of processes in $\mathrm{N}$ cycle is explained. In addition, the critical $\mathrm{N}$ emissions for the Life Cycle Inventory (LCI), namely, nitrification $\left(\mathrm{N}_{2} \mathrm{O}\right.$ and $\left.\mathrm{NO}_{\mathrm{x}}\right)$, nitrate leaching $\left(\mathrm{NO}_{3}^{-}\right)$, denitrification $\left(\mathrm{N}_{2}\right.$ and $\mathrm{N}_{2} \mathrm{O}$ ) and volatilization $\left(\mathrm{NH}_{3}\right)$ are detailed (Fig. 1) (Table 2).

Nitrate $\left(\mathrm{NO}_{3}^{-}\right)$leaching in agriculture can occur when excess nitrate fertilizer is applied and lost due to rain or irrigation, among other soil and crop properties, and through aerobic microbially driven nitrification of ammonium ions. $\mathrm{NO}_{3}^{-}$leaching is estimated in PEF, using the EF $0.44 \mathrm{~kg}$ $\mathrm{NO}_{3}^{-} / \mathrm{kg} \mathrm{N}$ and the amount of fertilizer applied. In SALCA, this estimate is made using a balance between inputs (fertilization and irrigation) and outputs (plant uptake and background nitrogen emissions) using simplified equations. The process is more complex in Daisy and Animo, where nitrate inputs come from atmospheric deposition, fertilizers and soil solution. They apply a water-balance model using Darcy's law (Cannavo et al. 2008).

Ammonia volatilization $\left(\mathrm{NH}_{3}\right)$ occurs typically when the nitrogen is in the form of urea, which can come mainly from animal manure or urea fertilizers. All models estimate $\mathrm{NH}_{3}$ volatilization in a similar yet limited way, applying $\mathrm{EF}$ or volatilized fertilizer fractions. In PEF, different EFs ( $\mathrm{kg} \mathrm{N} / \mathrm{kg} \mathrm{N}$ applied) are used, for instance, 0.15 for urea and 0.1 for ammonium nitrate. In SALCA, $\mathrm{NH}_{3}$ emissions depend on the type and quantity of fertilizer, $\mathrm{N}$ content of the fertilizer, $\mathrm{pH}$ and the air saturation deficit. In Animo and Daisy, volatilization is not a function of climate conditions or incorporation depth. Thus, the user must enter a value for a fraction of $\mathrm{NH}_{4}{ }^{+}$that evaporates after applying the fertilizer. It is important to highlight that only Animo takes into account the fertilizer application practices (e.g. broad
Table 2 Summary of the parameters considered by the models

\begin{tabular}{lcccc}
\hline Parameter & PEF & SALCA & Daisy & Animo \\
\hline Nitrogen fixation & & & $\mathrm{x}$ & \\
Decomposition & & & $\mathrm{x}$ & $\mathrm{x}$ \\
Immobilization/mineralization & & $\mathrm{x}$ & $\mathrm{x}$ & $\mathrm{x}$ \\
Nitrification & $\mathrm{x}$ & $\mathrm{x}$ & $\mathrm{x}$ \\
Atmospheric deposition & & $\mathrm{x}$ & $\mathrm{x}$ \\
Ammonium leaching & & $\mathrm{x}$ & $\mathrm{x}$ \\
Ammonium adsorption/desorption & & & $\mathrm{x}$ & $\mathrm{x}$ \\
Plant uptake & & $\mathrm{x}$ & $\mathrm{x}$ & $\mathrm{x}$ \\
Nitrate leaching & $\mathrm{x}$ & $\mathrm{x}$ & $\mathrm{x}$ & $\mathrm{x}$ \\
Denitrification & $\mathrm{x}$ & & $\mathrm{x}$ & $\mathrm{x}$ \\
Volatilization & $\mathrm{x}$ & $\mathrm{x}$ & $\mathrm{x}$ & $\mathrm{x}$ \\
\hline
\end{tabular}

sprayer, hose, injection), illustrating a limitation in the other models since many studies have found that practices can influence $\mathrm{NH}_{3}$ volatilization (Bittman et al. 2014; Søgaard et al. 2002; Brentrup et al. 2000; with an example of its site-specific application and use in Montemayor et al. 2019).

Nitrous oxide $\left(\mathrm{N}_{2} \mathrm{O}\right)$ emitted by soils can be produced by denitrification in anoxic conditions or by nitrification in the presence of $\mathrm{O}_{2}$, being an intermediate emission of incomplete nitrification and denitrification reactions. In PEF, $\mathrm{N}_{2} \mathrm{O}$ is estimated using the IPCC (2006) modified EF of $0.022\left(\mathrm{~kg} \mathrm{~N}_{2} \mathrm{O} / \mathrm{kg} \mathrm{N}\right.$ applied). SALCA considers direct (from nitrogen oxide (NO-N)) and indirect (from $\mathrm{NH}_{3}$ and $\left.\mathrm{NO}_{3}^{-}\right) \mathrm{N}_{2} \mathrm{O}$ emissions, using the EF of $0.01\left(\mathrm{~kg} \mathrm{~N}_{2} \mathrm{O}-\mathrm{N} / \mathrm{kg}\right.$ $\mathrm{N}$ applied) for that. $\mathrm{N}_{2} \mathrm{O}$ is estimated by Michaelis-Menten kinetics in Daisy, depending on the availability of $\mathrm{NH}_{4}{ }^{+}$ and general heterotrophic respiration. In Animo, $\mathrm{N}_{2} \mathrm{O}$ is estimated by an empirical equation that depends, among other parameters, on the concentration of $\mathrm{NH}_{4}^{+}$, the water content in the layer, temperature and $\mathrm{pH}$.
Fig. 1 Nitrogen cycle and main processes ( adapted from Abrahamsen and Hansen 2000)

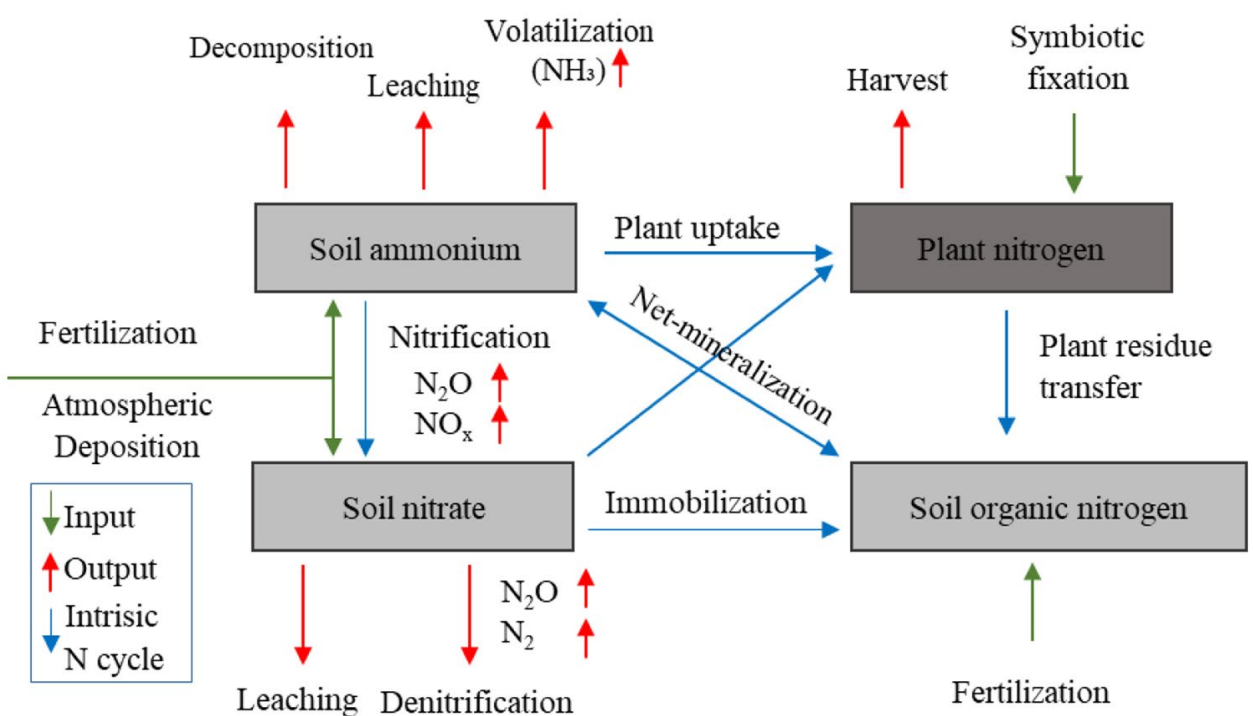

Leaching Denitrification
Fertilization 
Denitrification is the process by which $\mathrm{NO}_{3}^{-}$is reduced to $\mathrm{N}_{2}$ in a total reduction or $\mathrm{NO}_{2}$ and $\mathrm{N}_{2} \mathrm{O}$ in a partial reduction. In PEF, total denitrification producing $\mathrm{N}_{2}$ is assumed using the EF $0.09 \mathrm{~kg} \mathrm{~N}_{2} / \mathrm{kg} \mathrm{N}$ applied. Denitrification is not included in SALCA (Nemecek et al. 2016). In Daisy, denitrification is affected by temperature and water pressure and depends on a maximum fraction of converted nitrate, among other factors. Denitrification in Animo is considered a partial or complete reduction of available nitrate, depending on the respiration of organic matter, biodegradable organic matter, soil layer thickness and nitrate concentration. A denitrification rate is also required for limited nitrate conditions in Animo. For $\mathrm{NO}_{\mathrm{x}}$ emissions, SALCA uses IPCC (2006) $\mathrm{EF}, 0.012$ ( $\mathrm{kg} \mathrm{NO}_{\mathrm{x}}-\mathrm{N} / \mathrm{kg} \mathrm{N}$ applied), while PEF, Daisy and Animo do not estimate $\mathrm{NO}_{\mathrm{x}}$ emissions.

Other parameters not detailed in this section can directly and or indirectly affect the $\mathrm{N}$ emissions estimations. For instance, in mineralization, nutrients released as soluble inorganic bioavailable forms, and the roots' nitrogen uptake establish a balance between the crop's demand and the supply by the soil. Equations available are in the Supplementary Material.

\subsection{Description of the models and applied comparison metrics}

A set of different criteria and sub-criteria, based on UNFCCC (2004), Vidal-Legaz et al. (2016) and International Life Cycle Data (ILCD) (Wolf et al. 2010), were proposed to score and rank the models according to their user-friendliness and applicability for use as agricultural emission models in LCA studies. The criteria included are 'completeness of the model scope', 'environmental relevance', 'scientific robustness', 'availability, documentation, transparency and reproducibility', 'applicability and flexibility' and 'stakeholder acceptance' (Table 3). The possible scores were 1 (poor), 3 (good) and 5 (excellent).

\subsection{Case study: maize crop in Spain}

A case study was used to compare the estimates calculated using the models. A scenario of irrigated maize (2013-2017) in Mediterranean climate using calcium ammonium nitrate (CAN) as fertilizer was used (Table 4).

The minimum parameters required to estimate $\mathrm{N}$ emissions in the models are shown in Table 5 and Supplementary Material 2. Concerning Daisy and Animo's set up, a calibration was provided to align the models' outputs with real field measurements using yields from maize crop rotations (2013-2017). Default values for parameters in Daisy and Animo were taken from the models' library.

Note that although PEF seeks to standardize emissions for certain agricultural products, the low amount of input data required to estimate $\mathrm{N}$ emissions can result in lower accuracy and representativeness. It is important to highlight also that the pilot phase of PEF did not include cultivation in the foreground system, but it is under review for future assessments.

In Daisy, to reduce the effect of extreme weather conditions, a simulation was done for a 100-year simulation, applying randomized weather-crop combinations. In Animo, a 5-year simulation was performed to initialize an adjusted soil organic matter pool (SOM) for better estimates in the model.

An automatic irrigation $(30 \mathrm{~mm} / \mathrm{h}$ in case the water pressure in the soil falls below $-600 \mathrm{~cm}$ in the top $30 \mathrm{~cm}$ soil from May to September) had to be used in Daisy due to the impossibility to perform irrigation on specific days, as used in Animo. The nitrogen supplied by irrigation in SALCA was calculated multiplying the concentration of $\mathrm{N}$ in the water irrigation and total irrigation applied. Irrigation in SALCA was taken into account, adding it to monthly precipitation, in order to select a coefficient for soil leaching. For PEF, neither the $\mathrm{N}$ in irrigated water nor irrigation are considered.

Regarding the $\mathrm{N}$ estimates provided by Daisy and Animo, $\mathrm{NO}_{3}^{-}$leaching was calculated for the $100 \mathrm{~cm}$, depth of the root zone. $\mathrm{N}_{2} \mathrm{O}$ (nitrification and denitrification) and $\mathrm{NH}_{3}$ were estimated for the total soil profile. $\mathrm{NO}_{3}^{-}$leaching in SALCA was estimated for $90 \mathrm{~cm}$ of depth.

In the present work, the nitrogen balance in the field from the results obtained with the models includes as inputs: the mineral and organic fractions of fertilizers, atmospheric deposition, $\mathrm{N}$ in the irrigation water and fixation of atmospheric $\mathrm{N}$ by legumes. As sources of $\mathrm{N}$ production are losses to groundwater and surface water (via leaching and nitrate runoff), emissions to the atmosphere via ammonia volatilization, nitrification $\left(\mathrm{N}_{2} \mathrm{O}\right.$ and denitrification) and $\mathrm{N}$ absorption by crops and harvested $\mathrm{N}$. The stock of $\mathrm{N}$ (N inputs minus $\mathrm{N}$ outputs) in the soil is a positive value (increasing) that indicates the input $\mathrm{N}$ is greater than the output, contributing to the increase in the stock of $\mathrm{N}$. Otherwise, if the change in the stock of $\mathrm{N}$ is a negative (decreasing) value suggests liquid mineralization of organic $\mathrm{N}$ from the soil. Therefore, the crop is taking nitrogen out of the soil. The strategy adopted for the $\mathrm{N}$ balance is the same used in the Daisy and Animo models.

It is essential to highlight that emissions estimated in dynamic models day by day use precisely climate condition for the management operation performed, but much more detailed information is required, which can be an obstacle for LCA practitioners. The simulations made in Animo and Daisy were carried out in the most similar way possible, but, due to models' internal parameters, differences were found in the results provided.

The estimated emissions were inventoried in SimaPro software v. 8.5 (Pré Consultants 2017) using a scenario provided by Montemayor et al. (2019). The impacts were characterized using the ILCD 2011 midpoint method to verify how variations in emissions estimations influence LCA impact results. 
Table 3 Criteria for comparing the models from the perspective of LCA

\begin{tabular}{|c|c|c|}
\hline \multicolumn{2}{|l|}{ Criteria } & Description and scoring \\
\hline \multicolumn{3}{|l|}{ Completeness of the model scope } \\
\hline Geographic coverage & & $1=$ Local $; 3=$ Regional $; 5=$ Global \\
\hline \multicolumn{3}{|l|}{ Environmental relevance } \\
\hline \multirow[t]{2}{*}{ Spatial-temporal resolution } & Temporal resolution of the input & $\begin{array}{l}1=\text { Annual; } 3=\text { Seasonal; } 5=\text { Monthly or higher } \\
\text { resolution }\end{array}$ \\
\hline & Spatial resolution of the input & $\begin{array}{l}1=\text { Global } ; 3=\text { Regional/National; } 5=\text { Municipality } / \\
\text { farmer scale }\end{array}$ \\
\hline \multicolumn{3}{|l|}{ Scientific robustness } \\
\hline Transparency & & $\begin{array}{l}1=\text { No clear modelling explanation, not easily under- } \\
\text { stood; } 3=\text { Processes are clearly modelled but not } \\
\text { easily understood; } 5=\text { Processes are clearly modelled } \\
\text { and easily understood }\end{array}$ \\
\hline Input data set/data requirements & & $\begin{array}{l}1=\text { Extensive and detailed input parameters needed; } \\
3=\text { Application of a questionnaire in a farm, a } \\
\text { simple dataset for meteorological and soil physical } \\
\text { parameters; } 5=\text { Small and basic parameter input, data } \\
\text { obtained global databases or literature }\end{array}$ \\
\hline Emission model peer-review and (peers) acceptance & & $\begin{array}{l}1=\text { No (unpublished report); } 3=\text { Partially (book or } \\
\text { authoritative body report with some review process, } \\
\text { or partial publication in a journal, including all parts } \\
\text { of the model); } 5=\text { Yes (full peer-reviewed journal for } \\
\text { all aspects of the model) }\end{array}$ \\
\hline The model reflects up-to-date knowledge for the cause & se-effect chain & $\begin{array}{l}1=\text { not up-to-date; } 3=\text { partially up-to-date; } 5=\text { yes } \\
\text { (state-of-the-art) }\end{array}$ \\
\hline Tests of the emissions already conducted & & $\begin{array}{l}1=\text { No; } 3=\text { Tested for relevant products/scale and con- } \\
\text { ditions but showing important limitations; } 5=\text { Tested } \\
\text { for relevant products/scale, different conditions, peer- } \\
\text { reviewed and showing not relevant model limitations }\end{array}$ \\
\hline Uncertainty and sensitivity analysis & & $\begin{array}{l}1=\text { No; } 3=\text { Yes, but just for the outputs; } 5=\text { Yes, } \\
\text { including inputs and outputs }\end{array}$ \\
\hline \multicolumn{3}{|l|}{ Availability, documentation, transparency and reproducibility } \\
\hline Accessibility of the emission model & & $\begin{array}{l}\text { 1 = No free access/availability; } 3=\text { Available under } \\
\text { conditions/on request; } 5=\text { Free access/Internet } \\
\text { download }\end{array}$ \\
\hline Accessibility of the model documentation & & $\begin{array}{l}1=\text { Not accessible; } 3=\text { Accessible with limitations } \\
\text { (e.g. fee due, not available in the English language); } \\
5=\text { Totally accessible }\end{array}$ \\
\hline Accessibility of the input data & & $\begin{array}{l}1 \text { = High limitations (many input data not available in } \\
\text { global databases, also data not related to common in } \\
\text { LCA). } 3 \text { = Low limitations (some data too specific } \\
\text { and not available in regional database). } 5=\text { Totally } \\
\text { accessible, all data are relatively easy to obtain }\end{array}$ \\
\hline Modelling assumptions and value choices & & $\begin{array}{l}1=\text { Not described; } 3=\text { Unclear/partial description; } \\
5=\text { Comprehensive description }\end{array}$ \\
\hline Completeness of the emission model documentation & & $\begin{array}{l}1=\text { Very incomplete or no documentation; } 3=\text { Partially } \\
\text { comprehensive documentation; } 5=\text { Fully comprehen- } \\
\text { sive documentation }\end{array}$ \\
\hline \multicolumn{3}{|l|}{ Applicability and flexibility } \\
\hline Compatibility with LCA methodology & & $\begin{array}{l}1=\text { Not compatible; } 3=\text { Not developed for LCIA but it } \\
\text { fits the scope; } 5=\text { Developed for LCA and tested }\end{array}$ \\
\hline Usability of models for LCA practitioners & & $\begin{array}{l}1=\text { Not used; } 3=\text { Already used but in few situations; } \\
5=\text { Already used in several studies }\end{array}$ \\
\hline Related to IPCC TIER concept & & $1=$ Tier $3=$ Tier $2 ; 5=$ Tier 3 \\
\hline Management operations consideration & & $1=$ No $; 3=$ Partially includes $; 5=$ Totally includes \\
\hline
\end{tabular}


Table 3 (continued)

\begin{tabular}{lr}
\hline Criteria & Description and scoring \\
\hline Flexibility (Is it to change parameters and conditions in the model?) & $\begin{array}{r}1=\text { The model is static: no changes are possible; } \\
3=\text { Change of conditions and (dis)aggregation of } \\
\text { sources are possible; } 5=\text { The model can be easily } \\
\text { adapted to new conditions, and aggregation/disaggre- } \\
\text { gation of sources is possible }\end{array}$ \\
$\begin{array}{l}\text { Stakeholder acceptance } \\
\text { Model and model results }\end{array}$ & $\begin{array}{r}1=\text { Both difficult to understand; } 3=\text { One of them is dif- } \\
\text { ficult to understand; } 5=\text { Both easily understandable } \\
1=\text { No; } 3=\text { Yes, by one of several national bodies; } \\
\text { Authoritative body behind the model }\end{array}$ \\
$\begin{aligned} 5=\text { Yes, endorsed by multinational bodies } \\
1=\text { Individual research; } 3=\text { Well trusted on national } \\
\text { body; } 5=\text { Well trusted on international body }\end{aligned}$ \\
$\begin{array}{l}1=\text { Yes; } 3=\text { Partially; } 5=\text { No } \\
\text { Neutrality across industries, products, or processes }\end{array}$
\end{tabular}

\section{Results}

\subsection{Comparison under the criteria and sub-criteria proposed by UNFCCC and other authors for adequacy in the LCA studies}

The model with the best total score was Daisy with 91 (79\% of the maximum total score), followed by SALCA and Animo with 85 (74\%) and PEF with 77 (67\%). The percentage achieved for each model in the selected criteria is shown in Fig. 2 and Table 6. Detail scored will

Table 4 Main characteristics of the crop system used in the case study (Montemayor et al. 2019)

\begin{tabular}{|c|c|c|}
\hline \multicolumn{3}{|l|}{ Geographic parameters } \\
\hline \multicolumn{2}{|l|}{ Location } & $\begin{array}{l}\text { La Tallada } \\
\text { d'Empordà, } \\
\text { Girona }\end{array}$ \\
\hline \multicolumn{2}{|l|}{ Coordinates } & $\begin{array}{l}\text { 1: } \\
\quad \mathrm{N} 42.08^{\circ} \mathrm{L} \\
\text { E03.06 }\end{array}$ \\
\hline \multicolumn{2}{|l|}{ Climate } & Arid \\
\hline Soil type & - & Loam \\
\hline Soil depth & $\mathrm{m}$ & 0.7 \\
\hline Clay & $\%$ & 18 \\
\hline Silt & $\%$ & 48 \\
\hline Sand & $\%$ & 34 \\
\hline Organic matter & $\%$ & 2.5 \\
\hline Soil pH & - & 8 \\
\hline Content $\mathrm{N}$ in irrigation water & $\mathrm{kg} \mathrm{NO}_{3}^{-} / \mathrm{m}^{3}$ & 0.009 \\
\hline \multicolumn{3}{|l|}{ Crop data } \\
\hline Moorish maize yield & $\mathrm{t} \mathrm{DM} \mathrm{ha}^{-1}$ & 20.65 \\
\hline \multicolumn{3}{|l|}{ Fertilization } \\
\hline $\begin{array}{l}\text { Total calcium ammonium } \\
\text { nitrate (CAN) applied }\end{array}$ & $\mathrm{kg} \mathrm{N} \mathrm{ha}^{-1}$ & $170^{*}$ \\
\hline
\end{tabular}

* Maximum value allowed by the nitrate directive (EEC 1991) be explained in this section, and further elaborated in Supplementary Material.

\subsection{1 'Completeness of the model scope' and 'Environmental relevance'}

In 'Geographic coverage' sub-criteria, PEF, Daisy and Animo scored 5 due to their worldwide applicability. Daisy and Animo require a model calibration, and there is no spatial restriction for PEF due its simplicity. SALCA scored 3 because it was developed to estimate emissions in Europe or temperate climate in the Northern Hemisphere.

\subsection{2 'Scientific robustness'}

SALCA, Daisy and Animo models scored 5 for 'Transparency' because the processes to estimate nitrogen emissions were clearly modelled and well-explained, PEF scored 1 because the emission fractions used are not adapted to different climate conditions and the system processes for cultivation are non-transparent. It was assumed, also taking into account Nemecek et al. (2016), that the less the 'Input dataset/data requirements', the better the model, as it requires less effort and time from the LCA practitioner. Thus, PEF scored 5, SALCA 3 and Daisy and Animo 1 since the last two need more input data (Table 2).

Regarding 'Emission model peer review and (peers) acceptance', Daisy and Animo scored 5 because they are peer-reviewed. SALCA and PEF are provided as guidelines, receiving a score of 3 .

Daisy and Animo explain the entire nitrogen cycle and the interconnections within the cycle, receiving 5 in 'The model reflects up-to-date knowledge for the cause-effect chain'. SALCA and PEF failed to receive the maximum 
Table 5 Minimum parameters required to estimate nitrogen emissions using PEF, SALCA, Daisy and Animo

\begin{tabular}{|c|c|c|c|}
\hline & PEF & SALCA & Animo \\
\hline Weather data & - None & - Average monthly precipitation & $\begin{array}{l}\text { - Main characteristics of the weather station } \\
\text { - Typical max and min temperature in a year } \\
\text { - Dry deposition of } \mathrm{NH}_{4}^{+} \text {and } \mathrm{NO}_{3}^{-} \\
\text {- }\left[\mathrm{NH}_{4}^{+}\right] \text {and }\left[\mathrm{NO}_{3}^{-}\right] \text {in precipitation } \\
\text { - Global radiation }\left(\mathrm{W} / \mathrm{m}^{2}\right) \\
\text { - Precipitation }(\mathrm{mm} / \text { day) } \\
\text { - Reference evapotranspiration }(\mathrm{mm} / \text { day) } \\
\text { - Air temp. }\left({ }^{\circ} \mathrm{C}\right)(\operatorname{mean}) \\
\text { - Air temp. }\left({ }^{\circ} \mathrm{C}\right)(\max \text { and min only Animo) } \\
\text { - Wind Speed (Animo) }\end{array}$ \\
\hline Soil characteristics & - None & $\begin{array}{l}\text { - pH } \\
\text { - Slope } \\
\text { - N in soil } \\
\text { - Coefficient related to rain washing } \\
\text { - Leaching coefficient as a function of } \\
\text { the slope }\end{array}$ & $\begin{array}{l}\text { - Depth of the horizons, of max rooting, groundwater } \\
\text { and existence of drainage } \\
\text { For each soil horizon (A, B, C...) } \\
\text { - Clay (\%), Silt (\%) and Sand (\%) } \\
\text { - Humus (\%) } \\
\text { - C:N } \\
\text { - Bulk density } \\
\text { Mualem van Genuchten model: } \\
\text { - } \alpha \text { and n (shape parameters) } \\
-\mathrm{K}_{\text {sat }} \text { (saturated hydraulic conductivity } \mathrm{cm} / \mathrm{d} \text { ) }\end{array}$ \\
\hline Fertilizer & $\begin{array}{l}\text { - Amount } \\
\text { - Type } \\
\text { (for } \mathrm{NH}_{3} \\
\quad \text { emissions) }\end{array}$ & $\begin{array}{l}\text { - Type and amount } \\
\text { - N availability (organic fertilizers) }\end{array}$ & $\begin{array}{l}\text { - Dry matter fraction }(\%) \\
\text { - Total } \mathrm{C} \text { fraction }(\%) \\
\text { - Total } \mathrm{N} \text { fraction }(\%) \\
\text { - } \mathrm{NH}_{4}^{+}-\mathrm{N} \text { fraction }(\%) \\
\text { - } \mathrm{NH}_{4}^{+} \text {volatilization (emission fraction) }\end{array}$ \\
\hline $\begin{array}{l}\text { Crops and field manage- } \\
\text { ment activities }\end{array}$ & - None & $\begin{array}{l}-\mathrm{N} \text { uptake (fraction) } \\
-\mathrm{N} \text { content in the water irrigation }\end{array}$ & $\begin{array}{l}\text { - Type of crop } \\
\text { - Date of ploughing, fertilization, sowing, irrigation and } \\
\text { harvesting } \\
\text { - Information about storage organ (leaf, stem, stub) }\end{array}$ \\
\hline Average yields (annual) & - None & - None & $\begin{array}{l}\text { - Dry matter (ton DM/ha) } \\
\text { - Yield (ton/ha) } \\
\text { - N content (kg N/ha) }\end{array}$ \\
\hline
\end{tabular}

score because the models are not as detailed as Daisy and Animo.

Daisy and Animo had 'Tests of the emissions already conducted', scoring 5. Although SALCA (3) has been used in LCA studies, it is not well-validated and has restricted use. The climate data in PEF (3) is not representative, so inconsistencies can be found compared with field measurements. PEF, Daisy and Animo scored 3 in 'Uncertainty and sensitivity analyses', and SALCA scored 1 because there is no information about those analyses for the model.

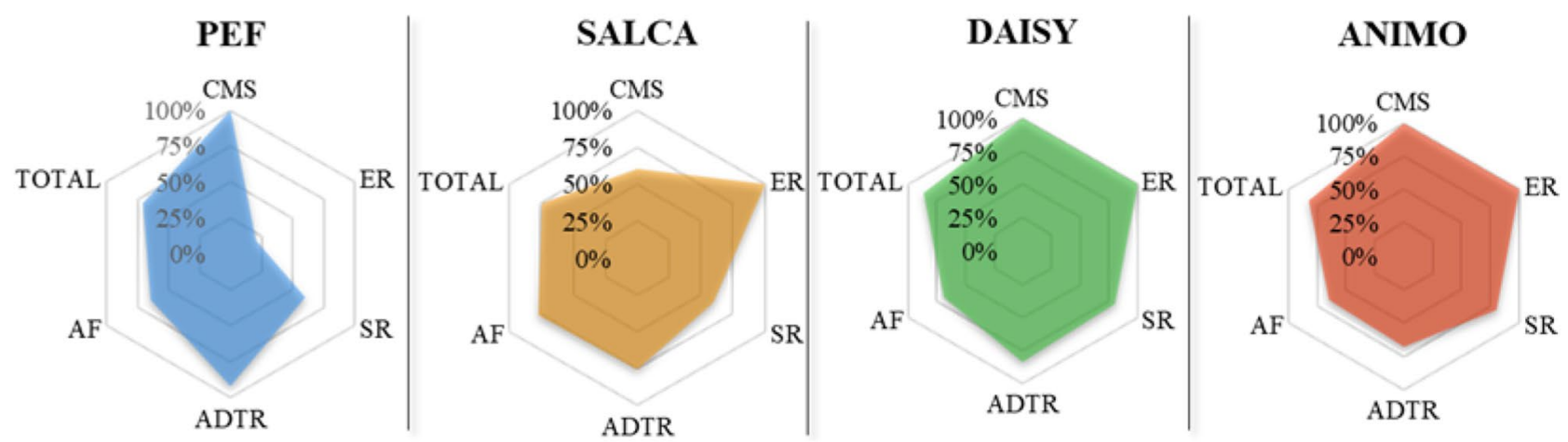

Fig. 2 Comparison of PEF, SALCA, Daisy and Animo under adapted methodology proposed by UNFCCC (2004) (ADTR availability, documentation, transparency and reproducibility, CMS completeness of

the model scope, ER environmental relevance, AF applicability and flexibility, SR scientific robustness) 
Table 6 Detailed scores regarding the qualitative assessment for comparing PEF, SALCA, Daisy and Animo models

\begin{tabular}{|c|c|c|c|c|c|}
\hline \multirow[t]{2}{*}{ Criteria and subcriteria } & & \multicolumn{4}{|c|}{ Models } \\
\hline & & PEF & SALCA & Daisy & Animo \\
\hline \multicolumn{6}{|l|}{ Completeness of the model scope } \\
\hline Geographic coverage & & 5 & 3 & 5 & 5 \\
\hline \multicolumn{6}{|l|}{ Environmental relevance } \\
\hline \multirow[t]{2}{*}{ Spatial-temporal resolution } & Temporal resolution of the input & 1 & 5 & 5 & 5 \\
\hline & Spatial resolution of the input & 1 & 5 & 5 & 5 \\
\hline \multicolumn{6}{|l|}{ Scientific robustness } \\
\hline Transparency & & 1 & 5 & 5 & 5 \\
\hline Input data set/data requirements & & 5 & 3 & 1 & 1 \\
\hline Emission model peer-review and (peers) acceptance & & 3 & 3 & 5 & 5 \\
\hline The model reflects up-to-date knowledge for the cause-effect chain & & 3 & 3 & 5 & 5 \\
\hline Tests of the emissions already conducted & & 3 & 3 & 5 & 5 \\
\hline Uncertainty analysis & & 3 & 1 & 3 & 3 \\
\hline \multicolumn{6}{|l|}{ Availability, documentation, transparency and reproducibility } \\
\hline Accessibility of the emission model & & 5 & 5 & 5 & 3 \\
\hline Accessibility of the characterization model documentation & & 5 & 3 & 5 & 5 \\
\hline Accessibility of the input data & & 5 & 3 & 1 & 1 \\
\hline Modeling assumptions and value choices & & 3 & 5 & 5 & 3 \\
\hline Completeness of the emission model documentation & & 5 & 3 & 5 & 5 \\
\hline \multicolumn{6}{|l|}{ Applicability and flexibility } \\
\hline Compatibility with LCA methodology & & 5 & 5 & 3 & 3 \\
\hline Usability of models for LCA practitioners & & 5 & 5 & 3 & 1 \\
\hline Related to IPCC TIER concept & & 1 & 3 & 5 & 5 \\
\hline Management operations & & 1 & 3 & 5 & 5 \\
\hline Flexibility & & 1 & 5 & 3 & 3 \\
\hline Model and model results & & 5 & 5 & 3 & 3 \\
\hline Authoritative body & & 5 & 1 & 1 & 1 \\
\hline Academic authority & & 1 & 3 & 3 & 3 \\
\hline Neutrality across industries, products, or processes & & 5 & 5 & 5 & 5 \\
\hline
\end{tabular}

\subsection{3 'Availability, documentation, transparency and reproducibility'}

PEF, SALCA and Daisy scored 5 because the models provide an easy 'Accessibility of the emission model'. PEF and SALCA provide documentation, and Daisy is an executable program, run in a text editor, that can be downloaded from of the University of Copenhagen website and uses its own programming language. Animo, though also an executable program run in a text editor, scored 3 because a request for access to the model is necessary.

SALCA scored 3 in 'Accessibility of the characterization model documentation' because the model is only available in German, which may represent a language barrier for many LCA practitioners. Daisy, Animo and PEF scored 5 because they provide useful documentation for a complete understanding of the models.
PEF scored 5 in 'Accessibility of the input data', because the amount and type of fertilizer are the only input data required. SALCA scored 3 as it is easy to obtain input data considering the inventory already created for the LCA study. Daisy and Animo scored 1 because some specific values may be more challenging to obtain, for instance, soil horizon characteristics, data for the groundwater or specific data related to the crop (e.g. leaves and roots).

Daisy scored 5 because it provides a document for 'Modelling assumptions and value choices', to help the user in cases with lack of data. SALCA and Animo scored 3 because assumptions are outlined in their reference documents. PEF scored 3 because it is not clear how the assumptions are made in the model, possibly due its simplicity. PEF, Daisy and Animo scored 5 in 'Completeness of the emission model documentation' because all the information required is described in the manuals. SALCA scored 3 since the manual was written for specific spatial conditions. 


\subsection{4 'Applicability and Flexibility'}

PEF and SALCA obtained the maximum score in 'Compatibility with LCA methodology' and 'Usability of models for LCA practitioners' because they were created to estimate emissions in LCA studies. Daisy and Animo scored 3 in the former criteria because they were not developed for LCA, but fall within the scope. Daisy scored 3 and Animo 1 in the latter subcriterion because Daisy has already been used to estimate emissions in LCA, but in Animo they did not implemented that aspect.

For the subcriterion 'Related to IPCC Tier concept', it was assumed that the model that best includes the dynamics on the environment (Tier 3 ) is the best model for LCA. Thus, PEF scored 1, SALCA 3, Daisy and Animo 5.

PEF scored 1 in 'Management Operations' because they are not considered in the model. SALCA scored 3 because some (e.g. irrigation) are relevant for the model. Daisy and Animo scored 5, since management operations are crucial for the models' performance.

PEF scored 1 in 'Flexibility' because the model applies $\mathrm{EF}$ as default methodology. However, in the guideline (EC-PEFCR 2018) it is said that other nitrogen field model can be used under certain conditions. SALCA scored 5, because changes and assumptions in the model are easy to carry out since the model is based on equations. Daisy and Animo scored 3, because changes are possible, but since many equations and processes are involved, it is more complex to perform and track those changes.

PEF and SALCA obtained the best score in 'Model and model results' since they are easy to understand. Daisy and Animo scored 3 because the results are easy to interpret, but understanding the models requires more effort.

No 'Authoritative body' supports the models; thus, SALCA, Animo and Daisy scored 1 in the subcriterion. PEF scored 5 because the emission model used was recommended by European Commission, a well-trusted international body. SALCA, Daisy and Animo scored 3 in 'Academic authority' as national research institutions provide them, and PEF scored 1 . All models also scored 5 in 'Neutrality across industries, products or processes' because they use an unbiased, objective methodology.

The models scored very similarly, with a difference of $8 \%$ in the total score. The comparison intended to show that many models can fit the LCA scope, but considering different purposes. Further work is needed through guidelines or other documents, in what situations they should be applied, and to force LCA practitioners to respect this adequacy as the scope of this study is to judge whether the models are suitable for LCA purposes in general.

Furthermore, when estimating and applying the emissions provided by the models in a case study, it is possible to identify the main differences and their effect on the impact categories in LCA when considering an entire system (e.g. machinery, water and fuel used).

\subsection{Quantitative comparison: a case study of maize crop in Spain (temperate/mesothermal climate)}

PEF, SALCA, Daisy and Animo were used to estimate nitrogen emissions due to the use of mineral fertilizers in an irrigated maize crop system in Spain. (Table 7). Approaches for Animo and Daisy's calibration included adjusting, for instance, rates of photosynthesis, $\mathrm{N}$ uptake by the crop and $\mathrm{N}$ concentration in different plant organs. After calibration, the simulated crop yields in Daisy and Animo were only - 3\% and $-4 \%$ of the observed yields, respectively, showing that the two models are able to produce reliable results for the system (Fig. 3).

None of the models estimated all parameters. The most worrying estimates not considered are denitrification in SALCA (possible overestimation of $\mathrm{N}_{2} \mathrm{O}$ emissions could increase the impact on climate change), and $\mathrm{NO}_{2}$ in PEF, Daisy and Animo (possibly increasing impacts on photochemical ozone formation, particulate matter and marine eutrophication). $\mathrm{N}$ from water irrigation in PEF, and dry and wet deposition in PEF and SALCA should be considered in the future as they can contribute to more $\mathrm{N}$ as input into the system. Seed's nitrogen supply was only considered in Daisy, but being $1 \%$ of the total input, it is not a significant loss for the other models in the present study. Irrigation was considered differently in Animo, Daisy and SALCA and is responsible for the $18 \%$ variation in $\mathrm{N}$ irrigation.

Animo estimated the highest nitrate leaching $(43.7 \mathrm{~kg} \mathrm{~N} /$ ha/year) and PEF the lowest (17 kg N/ha/year). SALCA and PEF do not consider the evapotranspiration in the soil, directly affecting the estimated emissions. In addition, irrigation modelled in Daisy may be decreasing the actual value of nitrate leaching, especially compared with Animo, since in Daisy less irrigation went to the crop system. The variation in results for nitrate leaching was $61 \%$. The loss of nitrate due to surface runoff estimated resulted in zero in Daisy and Animo.

SALCA estimated the highest $\mathrm{NH}_{3}$ volatilization (3.7 kg N/ha/year) and Daisy and PEF the lowest (3.4 kg N/ ha/year), varying by $8 \%$, being the lowest variation between the emissions. Although SALCA considers direct and indirect forms of ammonia volatilization, Animo considers the fertilizer application technique, and Daisy and Animo take into account the dry and wet deposition of $\mathrm{NH}_{4}{ }^{+}$ available in the air. Still, no significant difference was observed in the results.

SALCA is the only model that estimates $\mathrm{NO}_{2}$ emissions, which means more impacts will be attributed to the system. However, this represents an advantage for the model in terms of coverage of nitrogen emissions. 
Table 7 Average (2013-2017) nitrogen components estimated with the models PEF, SALCA, Daisy, Animo

\begin{tabular}{llllll}
\hline & Source & PEF & SALCA & Daisy & Animo \\
\hline Input (kg N/ha/year) & Fertilizer (mineral fraction) & 170 & 170 & 170 & 170 \\
& Deposition & - & - & 15.6 & 14.7 \\
& Irrigation & - & 8.3 & 6.8 & 6.2 \\
& Plant N fixation & - & 0 & 0 & 0 \\
& $\mathrm{~N}$ in soil & - & - & - & - \\
& Seed & - & - & 2.0 & - \\
& Total input & 170 & 178.3 & 194.4 & 190.9 \\
Output (kg N/ha/year) & Leaching to groundwater & 17.0 & 18.0 & 19.9 & 43.7 \\
& $\left.\quad(\mathrm{~N}-\mathrm{NO})^{-}\right)$ & & & & \\
& Loss to surface water & - & - & 0 & 0 \\
& $\mathrm{NH}_{3}$ Volatilization $\left(\mathrm{N}-\mathrm{NH}_{3}\right)$ & 3.4 & 3.7 & 3.4 & 3.6 \\
& NO & - & 1.2 & - & - \\
& Nitrification $\left(\mathrm{N}_{2}-\mathrm{N}_{2} \mathrm{O}\right)$ & 2.4 & 1.6 & 3.4 & $2.9^{2}$ \\
& Denitrification $\left(\mathrm{N}^{2} \mathrm{~N}_{2} \mathrm{O}\right.$ and $\left.\mathrm{N}_{2}\right)$ & $7.65^{1}$ & - & 6.7 & 0.7 \\
& $\mathrm{~N}$ uptake & 265.6 & 265.6 & 190.3 & 199.0 \\
& Total output & 296.8 & 290.1 & 223.7 & 249.9 \\
& Balance & -126.7 & -111.8 & -29.3 & -59.0 \\
\hline
\end{tabular}

${ }^{1} \mathrm{~N}_{2}$ emissions

${ }^{2} \mathrm{~A}$ fraction was used to separate $\mathrm{N}_{2} \mathrm{O}$ emissions
PEF and SALCA estimate $\mathrm{N}_{2} \mathrm{O}$ using EF, while Daisy and Animo consider the emission part from nitrification and another part from denitrification processes. In Daisy, the $\mathrm{N}_{2} \mathrm{O}$ is directly estimated, but in Animo a fraction of 0.005 (fraction for loam soils in temperate climate regions from de Vries et al. (2003)) was applied to assume the amount of $\mathrm{N}_{2} \mathrm{O}$ in total nitrification. In Animo and Daisy, a fraction of 0.02 (also from de Vries et al. (2003)) was applied to distinguish between $\mathrm{N}_{2}$ or $\mathrm{N}_{2} \mathrm{O}$ in the denitrification. For Daisy and Animo, $\mathrm{N}_{2} \mathrm{O}$ emissions from denitrification are 0.134 and $0.002 \mathrm{~kg} \mathrm{~N} /$ ha/year. In summary, $\mathrm{N}_{2} \mathrm{O}$ emissions ( $\mathrm{kg} \mathrm{N}-\mathrm{N}_{2} \mathrm{O} /$ ha/year) in PEF release 2.4, SALCA 1.6, Daisy 3.5 and Animo 2.9. The variation in $\mathrm{N}_{2} \mathrm{O}$ emissions was $54 \%$. Regarding denitrification, $\mathrm{N}_{2}$ emissions (an inert nitrogen emission) were considered for PEF.

The $\mathrm{N}$ uptake applied in PEF was the same as in SALCA. That said, SALCA applied the average yield and a crop uptake coefficient for N uptake $(13 \mathrm{~kg} \mathrm{~N} /$ ton DM). The variation in this output was $28 \%, 265.6 \mathrm{~kg} \mathrm{~N} / \mathrm{ha} /$ year in SALCA (highest) and $190.3 \mathrm{~kg} \mathrm{~N} / \mathrm{ha} /$ year in Daisy (lowest).

The highly negative $\mathrm{N}$ balance in PEF $(-126.7 \mathrm{~kg} \mathrm{~N} /$ ha/year) is due to the limitation of $\mathrm{N}$ inputs considered and the 'crop uptake' being much higher than those estimated in Animo or Daisy. The balance in SALCA was $-111.9 \mathrm{~kg} \mathrm{~N} /$ ha/year and did not consider $\mathrm{N}$ in soil and $\mathrm{N}$ mineralized as inputs into the system, although they have been used for $\mathrm{NO}_{3}^{-}$leaching estimates. Again, crop uptake is a major contributor to the nigh negative balance in SALCA. Animo had the highest $\mathrm{NO}_{3}^{-}$leaching output, resulting in an $\mathrm{N}$ balance of $-59.3 \mathrm{~kg} \mathrm{~N} / \mathrm{ha} /$ year. This high $\mathrm{NO}_{3}^{-}$leaching was the distinguishing parameter that caused high $\mathrm{N}$ balance variation (59\%) compared with the other mechanistic model Daisy, since other estimated emissions were similar. Daisy achieved the best balance $(-29.3 \mathrm{~kg} \mathrm{~N} / \mathrm{ha} /$ year $)$ compared with the other models, considering that, although negative, is the closest to zero. According to the balances, there was a decrease in the soil mineral nitrogen stock.
Fig. 3 Calibration of Daisy and Animo models using the yield for irrigated maize in Spain

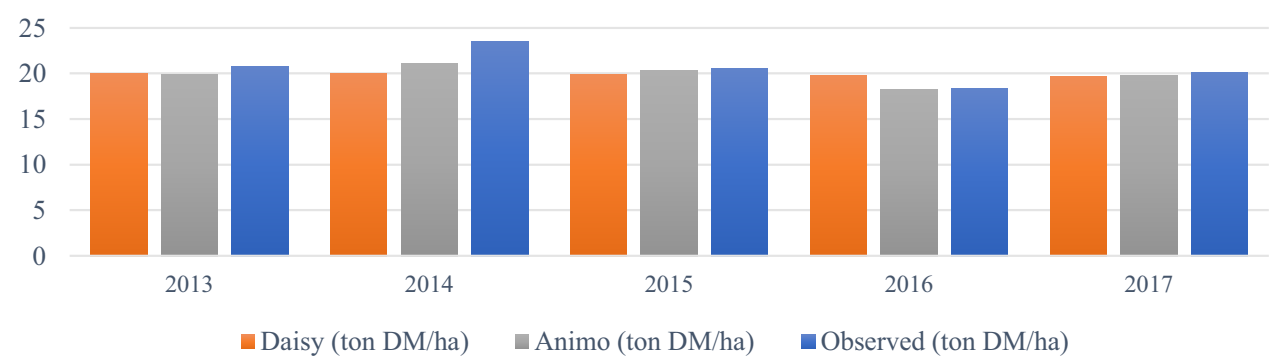


Table 8 Fertilizer emissions used in a Spanish maize crop life cycle inventory for each $\mathrm{N}$ emission model, PEF, SALCA, Daisy and Animo

\begin{tabular}{lccccl}
\hline $\mathrm{N}$ emission & PEF & SALCA & Daisy & Animo & Variation \\
\hline $\mathrm{N}_{2} \mathrm{O}(\mathrm{kg} \mathrm{N} 2 \mathrm{O} /$ ha/year $)$ & 3.8 & 2.5 & 5.5 & 4.6 & $54 \%$ \\
$\mathrm{NH}_{3}\left(\mathrm{~kg} \mathrm{NH}_{3} /\right.$ ha/year $)$ & 4.1 & 4.5 & 4.1 & 4.4 & $9 \%$ \\
$\mathrm{NO}_{2}\left(\mathrm{~kg} \mathrm{NO}_{2} /\right.$ ha/year $)$ & - & 5.3 & - & - & - \\
$\mathrm{NO}_{3}^{-}\left(\mathrm{kg} \mathrm{NO}_{3}^{-} /\right.$ha/year $)$ & 75.3 & 79.7 & 88.1 & 193.5 & $61 \%$ \\
\hline
\end{tabular}

\subsection{Characterization of impacts in an LCA of maize crop in Spain}

The impacts were characterized in the Simapro software (Pré Consultants 2017), using a scenario provided by Montemayor et al. (2019) and the models' emission estimates (Table 8). The impact categories analysed with the ILCD 2011 midpoint method were 'Climate change (CC)', 'Particulate Matter (PM)', 'Photochemical Ozone Formation (POF)', 'Acidification (AC)', 'Terrestrial Eutrophication (TE)' and 'Marine Eutrophication (ME)'. Impact assessment models recommended in ILCD 2011 (EC-JRC 2011) midpoint method are available in Supplementary Material 4.

The impacts were calculated for $1 \mathrm{t}$ of harvested maize dry matter (DM) (Table 9). Importantly, the variation in the values was caused only by the fertilizer emissions, since the ones related to machinery, fuels and other emissions were maintained the same as in Montemayor et al. (2019).

Although the impact variation among models was less than the variation in estimated emissions, the contribution of $\mathrm{N}$ from fertilizer input to impacts is evident. The 54\% variation in $\mathrm{N}_{2} \mathrm{O}$ emissions caused a $35 \%$ change in ' $\mathrm{CC}$ '. The $9 \%$ variation in $\mathrm{NH}_{3}$ emissions, caused a $1 \%$ change in the impact on 'PM' (smallest change in the calculated impacts), and an $18 \%$ change in 'TE'. For 'POF', only SALCA provided $\mathrm{NO}_{2}$ emissions, and these emissions caused a $31 \%$ change in impact. In 'AC', the $\mathrm{NH}_{3}$ and $\mathrm{NO}_{2}$ emissions caused a $14 \%$ change in the impact. The highest variation occurred in the impact category 'ME', with 56\% change caused by a $61 \%$ variation in the $\mathrm{NO}_{3}^{-}$leaching.
SALCA had the largest impacts on 'PM', 'POF', 'AC' and 'TE' due to the additional emissions of $\mathrm{NO}_{2}$, in addition to the emission of $\mathrm{NH}_{3}$. PEF emissions had the lowest impact in all impacts categories selected, except on 'CC'.

A normalization procedure was carried out using the UE27 2010 methodology (Benini et al. 2014; Crenna et al. 2019) to compare the total impact and impact categories in the proposed scenarios (Fig. 4). Animo emissions caused the highest impact in the system, with a normalized score of 4.09, followed by SALCA (3.42), Daisy (3.29) and PEF (3.13), varying $23 \%$ in the normalized impact caused, only changing nitrogen emissions from fertilizer application. The models presented the same decreasing order of contribution in the impact categories: 'PM', 'ME', 'TE', 'AC', 'CC' and 'POF'. However, the contribution of each impact category to the system is different. For instance, in 'PM', Daisy emissions contributed 25\%, but in Animo the contribution was $20 \%$ of the total impact; in 'ME', $38 \%$ of overall impact was attributed to the $\mathrm{NO}_{3}^{-}$leaching in Animo, but $22 \%$ in PEF. The different emissions directly affect the LCA final results, and this is also relevant when compared with other LCAs for irrigated maize crops or when calculating the system's uncertainties.

\section{Discussion}

\subsection{Comparison of model evaluation results with previous studies}

Other studies comparing the models selected in this study have been performed (Wu and McGechan 1998; Cannavo et al. 2008; Bockstaller et al. 2009; Nitschelm et al. 2018; Peter et al. 2016) for various reasons and using different approaches.

Wu and McGechan (1998) compared Animo and Daisy (older versions) with two other mechanistic models (SOILN and SUNDIAL). Their results showed that Animo and Daisy have similarities, especially related to the effects of temperature and water content in the soil, but in denitrification
Table 9 Impact characterization relevant to fertilizer emissions estimation using PEF, SALCA, Daisy and Animo models

\begin{tabular}{llrrrrr}
\hline Impact category & Unit & PEF & SALCA & Daisy & Animo & Variation \\
\hline $\mathrm{CC}$ & kg CO 2 eq/ton & 2669 & 2073 & 3175 & 2907 & $35 \%$ \\
$\mathrm{PM}$ & $\mathrm{kg} \mathrm{PM} 2.5$ eq/ton & 4.17 & 4.22 & 4.17 & 4.19 & $1 \%$ \\
$\mathrm{POF}$ & $\mathrm{kg} \mathrm{NMVOC}$ eq/ton & 8.42 & 12.26 & 8.42 & 8.42 & $31 \%$ \\
$\mathrm{AC}$ & molc H+eq/ton & 25.60 & 29.62 & 25.60 & 26.51 & $14 \%$ \\
$\mathrm{TE}$ & $\mathrm{kg} \mathrm{N} \mathrm{eq/ton}$ & 97.36 & 118.99 & 97.36 & 101.41 & $18 \%$ \\
$\mathrm{ME}$ & $\mathrm{kg} \mathrm{N} \mathrm{eq/ton}$ & 21.00 & 23.53 & 23.90 & 47.74 & $56 \%$ \\
\hline
\end{tabular}

CC climate change, PM particulate matter, POF photochemical ozone formation, AC acidification, TE terrestrial eutrophication, ME marine eutrophication 
Fig. 4 LCA results after normalization for impact categories associated with nitrogen emissions, for nitrogen emission models Animo, Daisy, PEF and SALCA

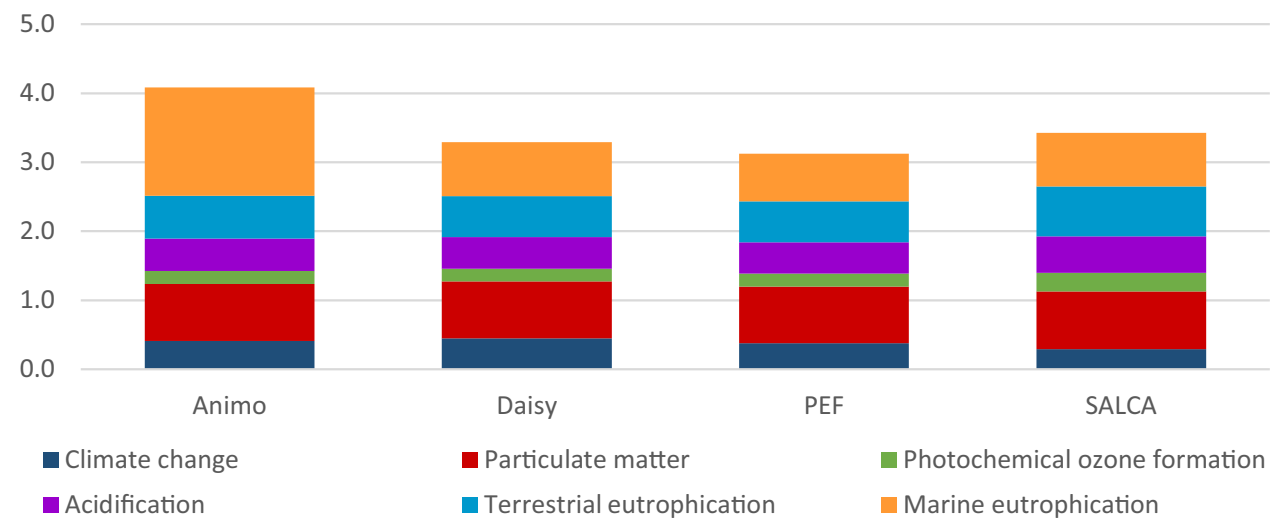

significant differences due to the applied parameters are present. They also pointed out that ammonia volatilization is modelled to a limited extent on both models, depending on the EF entered by the user. Agreeing Wu and McGechan (1998), denitrification in this study had an $89 \%$ difference between the Daisy and Animo estimates, and ammonia volatilization had only $8 \%$ of the difference between the models, being quite simplified even in the mechanistic models.

Cannavo et al. (2008) compared 62 mechanistic and empirical models, including Animo and Daisy, to assess environmental impacts of cultivated soils due to nitrogen emissions. Unlike this study, Cannavo et al. (2008) did not explain the simulated $\mathrm{N}$ processes. However, they pointed out that no lower performance was observed between empirical and mechanistic models, as long as the empirical models are applied in the specific context for which they were developed, respecting their geographic coverage, also spatial and temporal resolution required for the study's goal and scope. In summary, they said that mechanistic and empirical models would provide different results due to the models' internal parameters that were the same observed in the current work. The exception was for ammonia volatilization, in which all models obtained almost the same results, but this was expected since the models estimate ammonia volatilization simply and similarly.

Bockstaller et al. (2009) compared SALCA to three other models to test their capability as a farm management tool. SALCA obtained the best score for 'environmental scientific soundness' including coverage of agricultural production branches and coverage of production factors. However, SALCA was unable to cover all relevant environmental issues (e.g. biodiversity), and it was not considered user-friendly to farmers. Unlike the findings of Bockstaller et al. (2009), in the present study, SALCA is considered a user-friendly model compared with the mechanistic models, Daisy and Animo, but being related to the use by LCA practitioners.
Peter et al. (2016) and Torrellas et al. (2018) and compared Tier 1, Tier 2 and Tier 3 approaches to the estimation of greenhouse gases (GHG) in wheat crops and peach orchards, and emissions from a cow manure biogas plant in Catalonia, respectively. Both works used IPCC (2006) as Tier 1 model, Tier 2 model in Peter et al. (2016) was Bouwman et al. (2002) and in Torrellas et al. (2018) was regionalized EF to Catalonia. Regarding Tier 3 models, Peter et al. (2016) decided not to select any model justifying that, at the moment, there was no model readily available and easily implementable by the user, and Torrellas et al. (2018) used EF estimated from field measurement. Peter et al. (2016) found relevant differences in the estimates, up to $+50 \%$ between Tier 1 and Tier 2 models, similar to the current work (34\%). In Torrellas et al. (2018) the difference between the results from Tier 1 and Tier 2 models were $24 \%$, similarly obtained in the current work, and of $25 \%$ in average comparing Tier 1 and Tier 3 models, also similar to the $30 \%$ found in the present work. Both studies strongly recommended the use of higher Tier models to estimate nutrient emissions, and Peter et al. (2016) highlighted the convenient relation between reducing complexity and improving precision when using medium-effort (Tier 2 and Tier 3) models that is also expected and preferable to be applied in LCA studies.

Nitschelm et al. (2018) compared $\mathrm{NO}_{3}^{-}$and $\mathrm{NH}_{3}$ emissions provided by a Tier 3 model Syst' $\mathrm{N}$ in a cropping system with the emissions estimated using the risk tables provided by AGRIBALYSE (Koch and Salou 2015), frequently used in LCA and similar to SALCA. For nitrate leaching, AGRYBALYSE models estimated emissions up to $67 \%$ lower than those estimated using Syst' $\mathrm{N}$, similar to the differences found in this work, 58\%, comparing SALCA and Animo's results. Regarding $\mathrm{NH}_{3}$, the differences were from 28 to $63 \%$, thus higher than in the current work. In addition, the authors recommended Tier 2 and Tier 3 models for farming systems at regional scales, and Tier 1 models for more general assessments such as national environmental labelling of food products. 


\subsection{Comparison of simulation results provided by the models to field observations}

The validation of the models' simulation against field measurements is essential to confirm if the results are accurate. However, due to the lack of field measurement for that specific system (which is common in LCA), the results of the simulation were compared with other studies containing similar environmental conditions and field practices.

The estimated values for $\mathrm{N}$ uptake in irrigated maize under Mediterranean conditions ranged from 151 to $254 \mathrm{~kg} \mathrm{~N} / \mathrm{ha}$ (Berenguer et al. 2009), 262 to $333 \mathrm{~kg} \mathrm{~N} / \mathrm{ha}$ (Yaguie and Quílez 2010) and 155 to $300 \mathrm{~kg} \mathrm{~N} / \mathrm{ha}$ (Biau et al. 2012). Results obtained for N uptake in Daisy (190.3 kg N/ ha/year), Animo (199.1 kg N/ha) and SALCA (265.6 kg N/ ha) are in agreement with the interval found in field studies. Therefore, all models adequately estimated $\mathrm{N}$ uptake, despite the $28 \%$ variation in the estimated emissions.

In nitrate leaching Coefficient (NLC) in Mediterranean climate conditions, the interval for the nitrate leaching $(\mathrm{kg}$ $\mathrm{N}-\mathrm{NO}_{3}^{-} / \mathrm{kg}$ fertilizer applied) in irrigated maize crops was 0.11 to 0.37 (Lasa et al. 2011). Thus, SALCA (0.11), Daisy $(0.12)$ and Animo $(0.26)$ reached results similar to this value. The 0.10 in PEF is slightly below the minimum limit.

Bussink (1994) and Recio et al. (2018) observed rates of approximately $1.5 \%$ of total $\mathrm{N}$ applied using CAN ammonia volatilization under Mediterranean conditions. PEF (2.0\%), SALCA (2.2\%), Daisy (2.0\%) and Animo (2.1\%) reached rates very similar to those authors.

According to Cayuela et al. (2017), the general average EF $\mathrm{N}_{2} \mathrm{O}\left(\mathrm{kg} \mathrm{N}-\mathrm{N}_{2} \mathrm{O} / \mathrm{kg} \mathrm{N}\right.$ applied) for Mediterranean agriculture should be 0.005 , being half of the value proposed by IPCC (0.01) and a quarter of the recommended value in PEF (0.022). Cayuela et al. (2017) also proposed an EF for irrigated crops, 0.0063 . Therefore, $\mathrm{N}_{2} \mathrm{O}$ emissions in this work should be between 0.83 and $1.1 \mathrm{~kg} \mathrm{~N}-\mathrm{N}_{2} \mathrm{O} / \mathrm{ha}$. None of the models achieved these results, PEF and SALCA due to the EF applied, Daisy and Animo due to the uncertainty in $\mathrm{N}_{2} \mathrm{O}$ emissions from nitrification and denitrification.

Denitrification calculated under Mediterranean climate in Teira-Esmatges et al. (1998) showed that $\left(\mathrm{N}_{2} \mathrm{O}+\mathrm{N}_{2}\right)$ losses represented $1.7 \%$ to $13.6 \%$ of the total $\mathrm{N}$ fertilizer applied. Therefore, the expected emissions between 2.89 and $23.21 \mathrm{~kg} \mathrm{~N} / \mathrm{ha}$ were achieved by PEF and Daisy. The expected emissions values are summarized in Table 10.

\subsection{Nitrogen emission models used in agricultural LCA studies}

The use of IPCC (2006) EF for $\mathrm{N}_{2} \mathrm{O}$ emissions appears to be the standard practice in LCA studies. However, as explained in Cayuela et al. (2017), the proposed factors are not adjusted for some climates, and the use of default EFs can result in erroneous emissions, as it happened with PEF and SALCA results. Mechanistic models also have been used to estimate $\mathrm{N}_{2} \mathrm{O}$ emission in LCA, for instance, GREET 16 in Wang et al. (2007), DNDC in Goglio et al. (2014), and DAYCENT in Kim and Dale (2005). Although Animo and Daisy did not fall within the range of observed emission results, a better calibration of the models and an adjustment of internal parameters can be done, meaning that for $\mathrm{N}_{2} \mathrm{O}$ emissions, Tier 3 models, such Daisy and Animo, could provide more adjusted estimates.

EF's use for $\mathrm{NH}_{3}$ volatilization is widespread but from different sources other than IPCC (2006) used in PEF. Thomassen et al. (2008) and Xue et al. (2016) applied EF from previous studies that are more adjust to climate conditions than IPCC (2006) EF. Tier 2 models, such as SALCA, are an excellent alternative for reducing complexity and improving precision for $\mathrm{NH}_{3}$ volatilization. Tier 2 models were used in Mancuso et al. (2019), Romero-Gámez et al. (2014) and Wu et al. (2018), but a validation such as that carried out in this study is necessary.

Tier 3 models are more common for the $\mathrm{NO}_{3}^{-}$leaching estimations. The complexity of the estimate can vary
Table 10 Comparison between estimated emissions in PEF, SALCA, Daisy and Animo and literature values, where green means estimated emissions are within the range of observed results, red means they are not within the range, and grey means it is not applicable

\begin{tabular}{|c|c|c|c|c|c|}
\hline $\mathrm{N}$ parameter & Observed & PEF & SALCA & Daisy & Animo \\
\hline $\mathrm{N}$ uptake (kg N/ha) & $151-333^{1}$ & - & 265.60 & 190.30 & 199.10 \\
\hline $\mathrm{NO}_{3}^{-}$leaching (NLC) & $0.11-0.37^{2}$ & 0.10 & 0.11 & 0.12 & 0.26 \\
\hline Volatilization (\%) & $\sim 1.5 \%^{3}$ & $2.0 \%$ & $2.2 \%$ & $2.0 \%$ & $2.1 \%$ \\
\hline $\mathrm{N}_{2} \mathrm{O}\left(\mathrm{kg} \mathrm{N}_{2} \mathrm{O}\right.$ emitted/ha $)$ & $0.53-0.68^{4}$ & 3.8 & 2.5 & 5.5 & 4.6 \\
\hline Denitrification (kgN/ha) & $2.89-23.21^{5}$ & 7.65 & - & 6.70 & 0.70 \\
\hline Within the range & & \multicolumn{2}{|c|}{ Not within the range } & Not app & \\
\hline
\end{tabular}

\footnotetext{
${ }^{1}$ Berenguer et al. (2009); Yagüe and Quílez (2010); Biau et al. (2012)

${ }^{2}$ Lasa et al. (2011)

${ }^{3}$ Bussink (1994) and Recio et al. (2018)

${ }^{4}$ Cayuela et al. (2017)

${ }^{5}$ Teira-Esmatges et al. (1998)
} 
substantially under different climate conditions (i.e. dry and wet climate) and management operations (i.e. irrigation, free drainage and drainage with pipes). For example, DAYCENT in Kim and Dale (2005), DNDC in Goglio et al. (2014), STICS in Plaza-Bonilla et al. (2018) and Daisy, as aforementioned. Tier 1 models represented by different rates or EF have also been applied, for example, 0.25 for summer maize (Wang et al. 2007) and 0.26 for rice in Xue et al. (2016). Tier 2 models were applied in $\mathrm{NO}_{3}^{-}$leaching estimate in Romero-Gámez et al. (2014). For $\mathrm{NO}_{3}^{-}$leaching, Tier 3 models should be taken as first option to estimate this emission, since Tier 1 (PEF) and Tier 2 (SALCA) models may not be considering most parameters needed for a better estimate.

Usually, when authors use mechanistic models, all nitrogen emissions are estimated using the same model (Goglio et al. 2014; Kim and Dale 2005; Li et al. 2016; Plaza-Bonilla et al. 2018). The scientific advantage of using mechanistic models is the calibration performed, making the results more credible and appropriate to the system. For the validation in the aforementioned studies, literature data was used in Goglio et al. (2014) and Ni et al. (2019), as it was provided in this study. In Wang et al. (2007) validation was assumed from $\mathrm{Hu}$ (2004), another strategy that could be adopted in LCA. However, no validation of results can no longer be an option in LCA.

According to Nemecek et al. (2016), the ideal model should be practical; calculates the results easily, be siteand time-dependent (but to apply under a wide range of situations); and includes a collection of parameters and input data required. However, while no model complies all those important characteristics for LCA, mechanistic models, well-validated and calibrated for different situations, could be used to provide regionalized EF, as in Brown et al. (2002) and Yoshida et al. (2016), to be applied in lower Tier models to adjust $\mathrm{N}$ emissions.

\section{Conclusions}

PEF, SALCA, Daisy and Animo have important characteristics that make them useful and suitable for LCA, whenever their domains as fertilizer application emissions models are respected. Daisy was the model that best fitted to the criteria selected, achieving $77 \%$ of the total score. The proposed methodology could be used in other studies to compare models' suitability for estimating nitrogen or nutrients in LCA.

For the case study applied, the models estimated reliable results for almost all $\mathrm{N}$ emissions, except for $\mathrm{N}_{2} \mathrm{O}$. However, the characterization impact carried out showed differences in the impact categories analysed. Other crops should have their emissions estimated under different models to corroborate with the results in this work.

More research must go into emission model comparisons, describing more complex agricultural systems (including double crops, organic fertilizer including manure by-products, cultivation on substrates), to identify the best ways to estimate nitrogen emissions in LCA. Guidelines or methodologies are needed to guide the LCA practitioner to better describe and justify their agricultural inventory emissions choice. A sensitivity analyses that assess different models, literature values for similar crops, and field data could be used as a strategy to validate the results estimated.

Finally, it is not always possible to use mechanist models like Daisy or Animo to estimate nitrogen emissions in LCA, mostly due to the amount of input data required. However, after calibrations and validations, these models could be used to adjust $\mathrm{EF}$, according to different climate conditions, crops and fertilizers used in the simplest models, such as SALCA or PEF. Therefore, LCA can benefit from using agricultural models, helping to improve their evidence-based results and recommendations.

Supplementary Information The online version contains supplementary material available at https://doi.org/10.1007/s11367-021-01867-4.

Acknowledgements We thank the project Nutri2cycle (773682) for the full support during this work and the CERCA Programme/Generalitat de Catalunya.

Funding This project has received funding from the European Union's Horizon 2020 research and innovation programme under the Marie Skłodowska-Curie grant agreement No. 713679 and from the Universitat Rovira i Virgili (URV).

Open Access This article is licensed under a Creative Commons Attribution 4.0 International License, which permits use, sharing, adaptation, distribution and reproduction in any medium or format, as long as you give appropriate credit to the original author(s) and the source, provide a link to the Creative Commons licence, and indicate if changes were made. The images or other third party material in this article are included in the article's Creative Commons licence, unless indicated otherwise in a credit line to the material. If material is not included in the article's Creative Commons licence and your intended use is not permitted by statutory regulation or exceeds the permitted use, you will need to obtain permission directly from the copyright holder. To view a copy of this licence, visit http://creativecommons. org/licenses/by/4.0/. 


\section{References}

Abrahamsen P, Hansen S (2000) Daisy: an open soil-crop-atmosphere system model. Environ Model Softw 15(3):313-330

Berenguer P, Santiveri F, Boixadera J, Lloveras J (2009) Nitrogen fertilisation of irrigated maize under Mediterranean conditions. Eur J Agron 30(3):163-171

Benini L, Mancini L, Sala S, Manfredi S, Schau EM, Pant R (2014) Normalisation method and data for environmental footprints. European Union. EUR, Luxembourg, p 26842

Biau A, Santiveri F, Mijangos I, Lloveras J (2012) The impact of organic and mineral fertilizers on soil quality parameters and the productivity of irrigated maize crops in semiarid regions. Eur J Soil Biol 53:56-61

Bittman S, Dedina M, Howard CM, Oenema O, Sutton MA (2014) Options for ammonia mitigation: Guidance from the UNECE Task Force on Reactive Nitrogen. NERC/Centre for Ecology \& Hydrology

Bockstaller C, Guichard L, Keichinger O, Girardin P, Galan MB, Gaillard G (2009) Comparison of methods to assess the sustainability of agricultural systems: A review. Agron Sustain Dev 29(1):223-235

Bouwman AF, Boumans LJM, Batjes NH (2002) Modeling global annual $\mathrm{N} 2 \mathrm{O}$ and $\mathrm{NO}$ emissions from fertilized fields. Global Biogeochem Cycles 16(4):28-1

Brentrup F, Küsters J, Lammel J, Kuhlmann H (2000) Methods to estimate on-field nitrogen emissions from crop production as an input to LCA studies in the agricultural sector. Int J Life Cycle Assess 5(6):349

Brown L, Syed B, Jarvis SC, Sneath RW, Phillips VR, Goulding KWT, Li C (2002) Development and application of a mechanistic model to estimate emission of nitrous oxide from UK agriculture. Atmos Environ 36(6):917-928

Bussink DW (1994) Relationships between ammonia volatilization and nitrogen fertilizer application rate, intake and excretion of herbage nitrogen by cattle on grazed swards. Fertilizer research 38(2):111-121

Cannavo P, Recous S, Parnaudeau V, Reau R (2008) Modeling N dynamics to assess environmental impacts of cropped soils. Adv Agron 97:131-174

Cayuela ML, Aguilera E, Sanz-Cobena A, Adams DC, Abalos D, Barton L, Lassaletta L et al (2017) Direct nitrous oxide emissions in Mediterranean climate cropping systems: Emission factors based on a meta-analysis of available measurement data. Agric Ecosyst Environ 238:25-35

Crenna E, Secchi M, Benini L, Sala S (2019) Global environmental impacts: data sources and methodological choices for calculating normalization factors for LCA. The International Journal of Life Cycle Assessment 24(10):1851-1877. https://doi.org/10.1007/ s11367-019-01604-y

de Vries W, Kros J, Oenema O, de Klein J (2003) Uncertainties in the fate of nitrogen II: a quantitative assessment of the uncertainties in major nitrogen fluxes in the Netherlands. Nutr Cycling Agroecosyst 66(1):71-102. https://doi.org/10.1023/A:1023354109910

EEC (1991) Council Directive 91/676/EEC of 12 December 1991 concerning the protection of waters against pollution caused by nitrates from agricultural sources, OJ L 375,31.12.1991, p. 1

EC-JRC (2011) Recommendations for Life Cycle Impact Abessessment in the European context. Publications Office of the European Union, Luxemburg

EC-PEFCR European Commision (2018) Product Environmental Footprint Category Rules Guidance, version 6.3, May 2018

FAO (2018) Nutrient flows and associated environmental impacts in livestock supply chains. http://www.fao.org/partnerships/leap/ publications/en/
Farmaha BS (2014) Evaluating Animo model for predicting nitrogen leaching in rice and wheat. Arid Land Res Manag 28(1):25-35

Frischknecht R, Jolliet O (2016) (eds) Global guidance for life cycle impact assessment indicators-Volume 1. Publication of the UNEP/SETAC Life Cycle Initiative, Paris, DTI/2081/PA, ISBN: 978-92-807-3630-4:159

Goglio P, Grant BB, Smith WN, Desjardins RL, Worth DE, Zentner R, Malhi SS (2014) Impact of management strategies on the global warming potential at the cropping system level. Sci Total Environ 490:921-933

Groenendijk P, Renaud LV, Roelsma J (2005) Prediction of nitrogen and phosphorus leaching to groundwater and surface waters; process descriptions of the Animo 4. 0 model (No. 983). Alterra

Hansen S (2000) Daisy, a flexible soil-plant-atmosphere system model. Report Dept Agric p 615

Hansen S, Abrahamsen P, Petersen CT, Styczen M (2012) Daisy: model use, calibration, and validation. Transactions of the ASABE 55(4):1317-1333

Hendriks RF, van den Akker JJ (2017) Effectiveness of submerged drains in reducing subsidence of peat soils in agricultural use, and their effects on water management and nutrient loading of surface water: modelling of a case study in the western peat soil area of The Netherlands. In EGU General Assembly Conference Abstracts (Vol. 19, p. 17209)

Hendriks RF, Oostindie K, Hamminga P (1999) Simulation of bromide tracer and nitrogen transport in a cracked clay soil with the FLOCR/ANIMO model combination. J Hydrol 215(1-4):94-115

Hu ZY (2004) Study on methodology of life cycle assessment and multi-objective optimization for fuel ethanol. $\mathrm{PhD}$ thesis, Shanghai Jiao Tong University. Shanghai, China

IPCC (2006) 2006 IPCC guidelines for national greenhouse gas inventories, vol 5. Institute for Global Environmental Strategies, Hayama, Japan

Jabloun M, Xiaoxin L, Olesen JE, Schelde K, Zhang X, Tao F, Hu C (2016) Sensitivity analysis of the DAISY model applied to winter wheat-summer maize rotation in the North China Plain. In International Crop Modelling Symposium

Jensen MB, Møller J, Mønster J, Scheutz C (2017) Quantification of greenhouse gas emissions from a biological waste treatment facility. J Waste Manag 67:375-384

Kim S, Dale BE (2005) Life cycle assessment study of biopolymers (Polyhydroxyalkanoates) derived from no-tilled corn. Int J Life Cycle Assess 10(3):200-210. https://doi.org/10.1065/lca2004.08.171

Kløverpris JH, Bruun S, Thomsen IK (2016) Environmental life cycle assessment of Danish cereal cropping systems. DCA Rep, (081)

Koch P, Salou T (2015) AgriBALYSE®: methodology. France, ADEME, Angers, p 385

Kroes J, Roelsma J (2007) Simulation of water and nitrogen flows on field scale; application of the SWAP-ANIMO model for the Müncheberg data set. Modelling water and nutrient dynamics in soil-crop systems. Springer, Dordrecht, pp 111-128

Lasa B, Irañeta I, Muro J, Irigoyen I, Aparicio Tejo PM (2011) Isotopic composition of maize as related to $\mathrm{N}$-fertilization and irrigation in the Mediterranean region. Scientia Agricola 68(2):182-190

Li A, Duval BD, Anex R, Scharf P, Ashtekar JM, Owens PR, Ellis C (2016) A case study of environmental benefits of sensor-based nitrogen application in corn. J Environ Qual 45(2):675-683. https:// doi.org/10.2134/jeq2015.07.0404

Mancuso T, Verduna T, Blanc S, Di Vita G, Brun F (2019) Environmental sustainability and economic matters of commercial types of common wheat. Agricultural Economics-Zemedelska Ekonomika 65(4):194-202

Manevski K, Børgesen CD, Li X, Andersen MN, Abrahamsen P, Hu C, Hansen S (2016) Integrated modelling of crop production and nitrate leaching with the Daisy model. MethodsX 3:350-363 
Marinov D, Querner E, Roelsma J (2005) Simulation of water flow and nitrogen transport for a Bulgarian experimental plot using SWAP and ANIMO models. J Contam Hydrol 77(3):145-164

Montemayor E, Bonmatí A, Torrellas M, Camps F, Ortiz C, Domingo F, Riau V, Antón A (2019) Environmental accounting of closedloop maize production scenarios: manure as fertilizer and inclusion of catch crops. Resour Conserv Recycl 146:395-404

Mueller T, Jensen LS, Magid J, Nielsen NE (1997) Temporal variation of $\mathrm{C}$ and $\mathrm{N}$ turnover in soil after oilseed rape straw incorporation in the field: simulations with the soil-plant-atmosphere model Daisy. Ecol Model 99(2-3):247-262

Nemecek T, Dubois D, Huguenin-Elie O, Gaillard G (2006) Life cycle assessment of Swiss organic farming systems. Aspects of Applied Biology 79, What will organic farming deliver? COR 2006:15-18

Nemecek T, Bengoa X, Lansche J, Mouron P, Riedener E, Rossi V, Humbert S (2015) Methodological guidelines for the life cycle inventory of agricultural products, version 3.0. World Food LCA Database (WFLDB). Quantis and Agroscope, Lausanne and Zurich, Switzerland

Nemecek T, Schnetzer J, Reinhard J (2016) Updated and harmonised greenhouse gas emissions for crop inventories. Int J Life Cycle Assess 21(9):1361-1378

Ni Y, Mwabonje ON, Richter GM, Qi A, Yeung K, Patel M, Woods J (2019) Assessing availability and greenhouse gas emissions of lignocellulosic biomass feedstock supply - case study for a catchment in England. Biofuel Bioprod Biorefin 13(3):568-581. https://doi.org/10.1002/bbb.1967

Nitschelm L, Parnaudeau V, Vertès F, van der Werf HM, Corson MS, Viaud V, Aubin J, Walter C (2018) Improving estimates of nitrogen emissions for life cycle assessment of cropping systems at the scale of an agricultural territory. Environ Sci 52(3):1330-1338

Notarnicola B, Sala S, Anton A, McLaren SJ, Saouter E, Sonesson U (2017) The role of life cycle assessment in supporting sustainable agri-food systems: a review of the challenges. J Clean Prod 140:399-409

Perrin A, Basset-Mens C, Gabrielle B (2014) Life cycle assessment of vegetable products: a review focusing on cropping systems diversity and the estimation of field emissions. Int J Life Cycle Assess 19(6):1247-1263

Peter C, Fiore A, Hagemann U, Nendel C, Xiloyannis C (2016) Improving the accounting of field emissions in the carbon footprint of agricultural products: a comparison of default IPCC methods with readily available medium-effort modeling approaches. Int $\mathbf{J}$ Life Cycle Assess 21(6):791-805

Pinto VM (2016) Simulation of water and nitrogen dynamics in a Cerrado soil under coffee cultivation using SWAP and ANIMO models (Doctoral dissertation, Universidade de São Paulo)

Plaza-Bonilla D, Nogue-Serra I, Raffaillac D, Cantero-Martinez C, Justes E (2018) Carbon footprint of cropping systems with grain legumes and cover crops: a case-study in SW France. Agric Syst 167:92-102. https://doi.org/10.1016/j.agsy.2018.09.004

Pohanková E, Hlavinka P, Takáč J, Žalud Z, Trnka M (2015) Calibration and validation of the crop growth model daisy for spring barley in the Czech Republic. Acta Universitatis Agriculturae et Silviculturae Mendelianae Brunensis 63(4):1177-1186

Pré Consultants (2017) SimaPro 8.5.2.0. Amersfoort, The Netherlands

Recio J, Vallejo A, Le-Noe J, Garnier J, García-Marco S, Álvarez JM, Sanz-Cobena A (2018) The effect of nitrification inhibitors on $\mathrm{NH} 3$ and $\mathrm{N} 2 \mathrm{O}$ emissions in highly $\mathrm{N}$ fertilized irrigated Mediterranean cropping systems. Sci Total Environ 636:427-436

Rijtema PE, Kroes JG (1991) Nitrogen modeling on a regional scale. Nitrate Contamination. Springer, Berlin, Heidelberg, pp 81-95

Rockström J et al (2009) Planetary boundaries: exploring the safe operating space for humanity. Ecol Soc 14 (2). https://doi. org/10.5751/ES-03180-140232
Romero-Gámez M, Audsley E, Suárez-Rey EM (2014) Life cycle assessment of cultivating lettuce and escarole in Spain. J Clean Prod 73:193-203

Salazar O, Hansen S, Abrahamsen P, Hansen K, Gundersen P (2013) Changes in soil water balance following afforestation of former arable soils in Denmark as evaluated using the DAISY model. J Hydrol 484:128-139

Søgaard HT, Sommer SG, Hutchings NJ, Huijsmans JFM, Bussink DW, Nicholson F (2002) Ammonia volatilization from field applied animal slurry-the ALFAM model. Atmos Environ 36(20):3309-3319

ten Hoeve M, Bruun S, Jensen LS, Christensen TH, Scheutz C (2019) Life cycle assessment of garden waste management options including long-term emissions after land application. J Waste manag 86:54-66

Teira-Esmatges MR, Van Cleemput O, Porta-Casanellas J (1998) Fluxes of nitrous oxide and molecular nitrogen from irrigated soils of catalonia (spain). J Environ Qual 27(3):687-697

Thomassen MA, van Calker KJ, Smits MCJ, Iepema GL, de Boer IJM (2008) Life cycle assessment of conventional and organic milk production in the Netherlands. Agri Syst 96(1-3):95-107. https:// doi.org/10.1016/j.agsy.2007.06.001

Torrellas M et al (2018) Different approaches to assess the environmental performance of a cow manure biogas plant. Atmos Environ 177:203-213

UNFCCC (2004) Estimation of emissions from agriculture. Available in: https://unfecc.int/resource/docs/2004/sbsta/inf04.pdf. Accessed May 2019

Vidal-Legaz B, Sala S, Antón A, De Souza DM, Nocita M, Putman B, Teixeira RF (2016) Land-use related environmental indicators for Life Cycle Assessment. Luxembourg

Wang M, Wu W, Liu W, Bao Y (2007) Life cycle assessment of the winter wheat-summer maize production system on the North China Plain. Int J Sustain Dev World Ecol 14(4):400-407

Ward MH, Jones RR, Brender JD, De Kok TM, Weyer PJ, Nolan BT, Van Breda SG (2018) Drinking water nitrate and human health: an updated review. Int J Environ Res Public Health 15(7):1557

Wolf MA, Chomkhamsri K, Brandao M, Pant R, Ardente F, Pennington DW, Goralczyk M (2010) ILCD handbook-general guide for life cycle assessment-detailed guidance. Joint Research Centre European Commission, Ispra, Italy, pp 1-417

Wu L, McGechan MB (1998) A review of carbon and nitrogen processes in four soil nitrogen dynamics models. J Agric Eng Res 69(4):279-305

Wu H, Wang S, Gao L, Zhang L, Yuan Z, Fan T, Wei K, Huang L (2018) Nutrient-derived environmental impacts in Chinese agriculture during 1978-2015. J Environ Manage 217:762-774

Wuepper D, Le Clech S, Zilberman D, Mueller N, Finger R (2020) Countries influence the trade-off between crop yields and nitrogen pollution. Nature Food 1(11):713-719

Xue JF, Pu C, Liu SL, Zhao X, Zhang R, Chen F, Xiao XP, Zhang HL (2016) Carbon and nitrogen footprint of double rice production in Southern China. Ecol Indic 64:249-257. https://doi.org/10.1016/j. ecolind.2016.01.001

Yagüe MR, Quílez D (2010) Response of maize yield, nitrate leaching, and soil nitrogen to pig slurry combined with mineral nitrogen. J Environ Qual 39(2):686-696

Yoshida H, Nielsen MP, Scheutz C, Jensen LS, Bruun S, Christensen TH (2016) Long-term emission factors for land application of treated organic municipal waste. Environ Model Assess 21(1):111-124

Publisher's Note Springer Nature remains neutral with regard to jurisdictional claims in published maps and institutional affiliations. 